\title{
Revista do Departamento de Psicologia - UfF: 20 anos
}

\section{Luis Antônio Baptista}

Um amigo italiano, estudioso da cultura brasileira, certa vez me perguntou qual a diferença entre nostalgia e saudade, já que na língua italiana a palavra saudade é inexistente. Após um longo período de conversa deduzimos que nostalgia seria o desejo do retorno de algo valioso do passado, o apego a fatos ou pessoas ameaçadas de perderem os seus rastros em nossas lembranças. A saudade, ao contrário, não almejaria a recuperação de algo que passou, a restauração do acontecimento consumado, e sim a experiência do mais uma vez, o experienciar no presente o passado não esgotado, o desejar o por vir. A nostalgia despreza o agora; ela não quer o mais uma vez na sua possível diferença, a intensidade do inacabado, mas o retorno literal da verdade do outrora. Da nossa conversa em Roma deduzimos que saudade era desejo de futuro. Lembro deste episódio como um alerta afetuoso para contar, de modo breve, como foi criada a nossa revista. Ela nasceu no bar da Dona Sônia, um botequim próximo ao antigo prédio da Psicologia. Semanalmente um grupo de professores reunia-se para tomar cervejas após o trabalho, conversar assuntos sérios e jogar conversa fora. Ríamos, brigávamos, falávamos ruidosamente no bar da chilena refugida no Brasil após o golpe militar no Chile. Vivíamos a segunda metade dos anos oitenta: o luto pela morte de Foucault, as polêmicas da constituinte, o massacre dos estudantes na China, as publicações dos exilados recém chegados, o cotidiano do departamento, as greves, isto tudo misturado as nossas dúvidas e desejos nesta década peculiar. Falávamos muito, divergíamos muito, atravessados por esta história plena de promessas e sobressaltos. Entre cervejas e o constante alarido das nossas enfáticas avaliações existiam afetos que perduravam após a interminável saideira. No dia seguinte os efeitos destes encontros tramados no pé sujo invadiam nossas aulas impedindonos a apatia ou o tédio pelos acontecimentos contemporâneos. Tínhamos tempo e o usávamos com vida. O Brasil tentava mudar, o mundo entrava ruidosamente

\footnotetext{
${ }^{2}$ Professor do Departamento de Psicologia da Universidade Federal Fluminense. Endereço: Campus do Gragoatá, s/ nº, bloco O, $2^{\circ}$ Andar, Sala 218, Gragoatá, CEP: 24210-350 - Niterói - RJ - Brasil.

Email: gsi@vm.uff.br
} 
no botequim da Dona Sônia, e nós, misturados a isto tudo desejávamos algo que se diferenciasse das conservadoras publicações da Psicologia. Em uma noite de 1988 eu, Júlio, Silvia, Luigi, Manoel, ${ }^{3}$ inventamos a revista.

O bar acabou, não nos reunimos mais, não temos tempo, o mundo mudou, a universidade é outra, as sociabilidades inspiram-se nas conveniências da produtividade, agora passamos, circulamos, corremos e nada acontece. O botequim fechou, mas permanece o ruído que produziu a nossa revista, à semelhança do eterno da arte definido por Baudelaire, o eterno que transgride os limites do irremediável, que viola os limites do concluído, aquilo que faz a história respirar para um próximo golpe ou corte. Uma alegre saudade me diz que algo poderá acontecer, mesmo sem a nossa interminável saideira.

\footnotetext{
${ }^{3}$ Nota dos Editores: Neste trecho Luis Antônio refere-se aos professores: Júlio Carlos Figueiredo, Sílvia Josephson, Luigi Moscatelli, Manoel Vital Fernandes, membros do Conselho Editorial do primeiro número da Revista do Departamento de Psicologia - UFF. Além destes docentes, compunham o Conselho Editorial: Angela Fernandes, José Novaes, Luis Antônio dos Santos Baptista, Margarida Gouveia, Teresa Cristina Carreteiro. Todos os membros do Conselho Editorial eram professores do Departamento de Psicologia - UFF. Nesta época a Revista não contava com a figura do Editor Responsável, sua gestão ficava a cargo do Conselho Editorial e da Comissão Executiva composta pelos professores Luis Antônio dos Santos Baptista e Sílvia Josephson.
} 